\title{
Sustainable cities: do political factors determine the quality of life?
}

\author{
J. M. Prado, I. M. García \& B. Cuadrado \\ Departamento de Administración y Economía de la Empresa, \\ Universidad de Salamanca, Spain
}

\begin{abstract}
The implementation of urban sustainability practices is affected by political obstacles, in that the policy or the objectives sought either involve the deflection of resources initially allocated to other groups or are contrary to the concerns pursued by interest groups who have the power to veto them by exerting pressure on the party in power. In this sense, the aim of this paper is to evidence the impact that political factors have on cities' sustainability, and the effect of the latter on cities' business development. The results obtained showed that political competition has a positive effect on cities' sustainability, while a leftist ideology has an inverse impact. On the other hand, a significant direct relationship has been observed between urban sustainability and municipal economic activity.

Keywords: urban sustainability, city's quality of life level (QOL), economic development, sustainable development, social sustainability, sustainability practices, political factors.
\end{abstract}

\section{Introduction}

In the 1980s and 1990s, cities contributed to the growth and development of the global economy but, paradoxically, did little to provide a basis for long-term sustainable urban growth (Konvitz [1]). Their behaviours are quite contradictory since cities' sustainability widely impacts business recruitment and investment (Glaser [2]; Insch and Florek [3]), parameters that could have a positive feedback effect on QOL.

Political factors are one of the obstacles to the implementation of urban sustainability practices. In this sense, Hogwood and Gunn [4] argue that the policy or the objectives sought could involve a deflection of resources initially 
allocated to other groups or could be contrary to the concerns of these interest groups (such as party activists, trade unions, etc.) who have the power to veto them by exerting pressure on the party in power. This opposition is more important in cases of weak or fragmented governments, that is, those that lack an absolute majority and therefore cannot impose their decisions with only the votes of their own party. Moreover, certain political ideologies are more favourable to sustainable policies than others (García-Sánchez and Prado-Lorenzo [5]).

In this sense, the aim of this paper is dual: on one hand, it is to evidence the impact that political factors have on cities' sustainability and on the other hand, it is focused on observing the effect of sustainable development on cities' business development. The methodology is based on linear regression models, controlling, in line with previous papers, for population density.

Since cities' sustainability is rather diffuse concept that is difficult to reach consensus on, some authors, such as Rotmans and Van Asselt [6], include economic as well as socio-cultural and environmental aspects in an effort to delimit the meaning of the term and be able to work with it. In this sense, one of the approaches most employed to determine the degree of sustainability is the city's quality of life level (QOL). In this study, cities' QOL has been measured using the score obtained by each Spanish city in the mercoCiudad (Spanish Corporate Reputation Monitor for Cities) analysis carried out in 2008 and 2009 for 78 Spanish municipalities.

The results obtained show a strong relationship between political factors and urban sustainability. More concretely, we have found that political competition has a positive effect on cities' sustainability, improving urban sustainability, while a leftist ideology has an inverse impact that negatively affects the citizens' quality of life. In relation to the subsequent effect that urban sustainability has on municipal economic development, a significant direct relationship was observed between urban sustainability and all municipal economic activity (industry, commerce and services).

\section{Sustainable cities and their economic development}

Sustainable development has become one of most important issues that society has had to face in recent years (Wang and Lihua [7]). Sustainable development is defined as that which "meets the needs of the present without compromising the ability of future generations to meet their own needs" (World Commission on Environment and Development, WCED, [8]) and presents a pathway to all that is good and desirable in a society (Zeijl-Rozema et al. [9]).

A sustainable city is broadly defined by The Regional Environment Center for Central and Eastern Europe as "one that has put in place action plans and policies that aim to ensure adequate resource availability and (re-) utilisation, social comfort and equity and economic development and prosperity for future generations". The concepts integrated in sustainable development are quite broad and although there is no consensus on these related points, all research studies think that all of them are desirable social goods (Dempsey et al. [10]) and have a triple bottom line perspective: economic, social and environmental. 
One of the approaches most employed to determine the level of municipal sustainability is the measurement of city quality of life, image or reputation as an integrated approach to addressing key social, environmental and economic determinants of health (Glaser [2]; Williams et al. [11]).

The residents' level of satisfaction with a place is considered a 'soft factor' during the business investment decision-making process (Biel [12]) because in the competitive arena of business investment attraction (outsiders), local politicians need to demonstrate convincingly that their city's residents enjoy a higher level of well-being and satisfaction than those of rival locations so that company executives, management and their families will decide to relocate and invest there (Insch and Florek [3]). There are also impacts on the investment by current members of the business community (insiders) (Glaser [2]). Furthermore, quality of life is directly related to other factors that are considered during this process such us local labour markets, infrastructure, transportation, education and training opportunities (Kotler et al. [13]).

In this sense, we proposed the first hypothesis of our paper:

H1: There is a positive relationship between the sustainability of a city and its economic development.

As economic factors that can be affected by a city's sustainability, we decided to include the following indicators in the analysis: INDUSTRY INDEX, WHOLESALE TRADE INDEX, RETAIL TRADE INDEX, and SERVICES INDEX, which represent the level of municipal development for these activities with respect to the national total.

\section{Political factors and sustainability}

Campbell [14] and Blowers [15] argue that the procedural path to sustainable development is fraught with conflicts as a reflection of the complex decisionmaking environment necessary to pursue and balance the three main goals of environmental protection, social equity, and economic development.

Political support given to planning process activities has also been addressed in the literature and it is considered essential for translating initial community interest into specific plan policies which become part of an adopted plan (Berke and French [16]; Berke et al. [17]).

The Public Choice theory provides an analysis of the complex political environment in which voters, interest groups and politicians play an important role in government decisions to adopt particular policies, globally (Mueller [18]), and sustainable plans, specifically. Politicians are the main actors in the decisionmaking about the future development of a city. They play the role of agents appointed through an electoral process and always act in order to maximize the number of votes they expect to receive in the next election. To do so, they select a given amount of effort (resources, agent's time, expertise, financial means) to provide policies to voters, in exchange for votes, and to interest groups, in exchange for resources, insofar as these can be reinvested to affect electoral outcomes (Bavetta and Padovano [19]). 


\subsection{Political ideology and stability}

The dominant party affiliation of a legislative body can affect sustainable urban development because contrary ideologies may defend different styles of cities; it is therefore necessary to analyse whether the political trend of the ruling party can have any impact - either positive or negative - on it. The scarce previous studies which have analysed this issue have found a negative influence of rightwing parties on the implementation of Local Agenda 21 (García-Sánchez and Prado-Lorenzo [5]). Nonetheless, there is not enough previous evidence that can predict which political tendency may be more prone to favouring local sustainability. Thus, we have formulated the following hypothesis:

H2: There is a positive relationship between a leftist political ideology of the governing party and the sustainability of a city.

To test the hypothesis proposed we use a dummy variable as an independent variable, LEFT IDEOLOGY. This variable takes the value 1 if the governing party is of a leftist ideology and 0 , otherwise. This information was obtained from the website of the Spanish Interior Ministry (www.mir.es).

At the same time, a greater or lesser level of political stability may lead to the advancement of or a halt in the activities related to sustainability, because the implementation of these measures tends to require having the proper support to choose to assign resources, with effects detectable only in the medium to long term.

In this sense, and although García-Sánchez and Prado-Lorenzo [5] observed that the overall degree of development of Local Agenda 21 is not affected by political stability, Prado-Lorenzo and García-Sánchez [20] evidenced that political stability is extremely important for executing the sustainability action plan designed. In accordance with the theoretical arguments, we proposed the following hypothesis:

H3: There is a positive relationship between the political stability of the governing party and the sustainability of a city.

We developed the variable STABILITY with the purpose of testing this hypothesis. It is measured from the percentage of votes achieved by the governing political party in the latest presidential elections. This information was obtained from the website of the Spanish Interior Ministry (www.mir.es).

\subsection{Political competition}

Party composition alone may not be able to capture the complex political environment of sustainability policy decision-making. As the political competition increases, the checks and balances of political control will prevent overreliance on political decisions (Ni and Bretschneider [21]) and a favourable environment for reforms could be created.

On the other hand, Smith and Fridkin [22] argue that interparty competition plays a key role in the decision of politicians to devolve institutional power to citizens so that they have to pay attention to the demands of their constituents. In this sense, public programs are more representative of the desires of the whole population of a state, rather than just those of the ruling elites. 
According to theoretical arguments, the following hypothesis has been formulated:

H4: The level of political competition positively influences the sustainability of a city.

In order to test this hypothesis we use the variable PARTIES measured by the number of political parties taking part in the latest general elections. This information was obtained from the website of the Spanish Interior Ministry (www.mir.es).

\subsection{Voter and interest groups}

Voters and interest groups, respectively, channel votes and resources to the centre of power that best satisfies their objectives, so they can influence the policy implementation decisions of the political leadership (Bavetta and Padovano [19]), including sustainability policy decisions. Thus, these actors are expected to be particularly interested in participating in public decision-making in order to obtain more benefits.

Traditionally, socioeconomic variables are used as surrogates for these actors, given that a higher economic and educational status usually leads to a higher participation and voting rates; in addition, as society increases in population and urbanization, diverse organizations develop to represent their interests (Cheng [23]). We thus have hypothesis H5:

H5: Voters and interest groups positively influence the sustainability of a city.

Previous papers have generally used the variables representing the municipal population and GDP to identify these groups. With respect to the first variable, it must be pointed out that a control variable of population density has to be entered subsequently, and that there is a high correlation with the population variable, so it cannot be used. As regards GDP, it was not available for the fiscal years analysed. Thus, in order to test hypothesis H5, we use the level of municipal unemployment, variable UNEMPLOYMENT, as a proxy of citizens' economic level.

\section{Methodology}

\subsection{Population}

The population selected consists of the 78 Spanish cities with a population over 100,000 for which MERCO carried out a study of their levels of sustainability for the fiscal years 2008 and 2009. The rest of the statistical data needed for the analysis were obtained from the Economic Directory (Anuario Económico) of La Caixa and the Spanish Interior Ministry.

\subsection{Variables}

\subsubsection{Dependent variables}

As dependent variables, we used the economic development of the municipality and the sustainability of the city. The economic development of the municipality 
was measured by different indicators devised as a function of the economic activity tax: Industry index (a comparative index of the importance of the city's industry, including construction, with respect to the whole of Spain), Wholesale trade index (a comparative index of the importance of the city's wholesale trade, with respect to the whole of Spain), Retail trade index (a comparative index of the importance of the city's retail trade, including construction, with respect to the whole of Spain ) and Services index ( comparative index of the importance of the city's restaurant and bar industry, with respect to the whole of Spain ).The city's sustainability (CSUS), as indicated above, was measured using the score obtained by each of the Spanish cities in the mercoCiudad analysis.

\subsubsection{Independent and control variables}

Table 1 provides a synthesis of the independent variables needed to test the proposed hypotheses, as well as the control variables used to avoid bias in the analysis. In relation to control variables there is a general assumption that cities of differing sizes and types to achieve consistently high levels of collective welfare illuminates both the strength and potential vulnerability of large metropolitan agglomerations, which are more powerful attractors of enterprises, symbols of economic power and modernity, but also extremely expensive machines, engendering enormous social and environmental strains (Camagni [24]). However, several aspects of sustainability, such as the environment, urbanization, social and quality of life are more highly related to population density (Camagni [24]). The consideration of population density and its strong correlation with the factors that form it, population and surface, make it impossible to use the three variables together in the analysis models.

\subsection{Research models}

Based on the variables selected to check the hypotheses proposed, we have defined the following models (1) and (2). In model 1, the economic development

Table 1: $\quad$ Independent and control variables.

\begin{tabular}{lccc}
\hline Variable & Hypothesis & Relation & Definition \\
\hline $\begin{array}{l}\text { CSUS } \\
\text { LEFT } \\
\text { IDEOLOGY }\end{array}$ & H1 & + & $\begin{array}{c}\text { Numerical variable that reflects the sustainability of the } \\
\text { municipality. }\end{array}$ \\
STABILITY & H3 & + & $\begin{array}{c}\text { Dummy variable that takes the value } 1 \text { if the governing } \\
\text { party has a leftist ideology and } 0, \text { otherwise. } \\
\text { Numerical variable measured from the percentage of votes } \\
\text { achieved by the governing party in the latest elections. } \\
\text { Numerical variable measured by the number of political } \\
\text { parties taking part in the latest general elections. } \\
\text { Numerical variable measured by the percentage of } \\
\text { unemployed citizens. }\end{array}$ \\
$\begin{array}{l}\text { UNEMPLOY- } \\
\text { MENT }\end{array}$ & H4 & + & $\begin{array}{c}\text { Numerical variable measured by the ratio municipality } \\
\text { population to the surface area in } \mathrm{Km}^{2} .\end{array}$ \\
DENSITY & &
\end{tabular}


will depend on the sustainability of the city and on political factors. In model 2 , the level of sustainable urban development will depend on a set of political factors.

Economic development $=\mathrm{f}($ Density, Political Factors, Sustainability $)$

Sustainability of the city $=\mathrm{f}$ (Density, Political Factors)

Model (1) can be estimated empirically from model (3):

ED $_{\mathrm{i}}=\beta_{0}+\beta_{1}$ DENSITY $_{\mathrm{i}}+\beta_{2}$ LEFT IDEOLOGY $_{\mathrm{i}}+\beta_{3}$ STABILITY ++ $\beta_{4}$ PARTIES $+\beta_{5}$ UNEMPLOYMENT $+\beta 6 \mathrm{SoC}+\varepsilon$

Model (2) can be estimated empirically from model (4):

SoC $_{\mathrm{i}}=\beta_{0}+\beta_{1}$ DENSITY $_{\mathrm{i}}+\beta_{2}$ LEFT IDEOLOGY $_{\mathrm{i}}+\beta_{3}$ STABILITY $+^{+}$ $\beta_{4}$ PARTIES $+\beta_{5}$ UNEMPLOYMENT $+\varepsilon$

where ED is the dependent variable proposed to identify the economic development of each city, CSUS is the dependent and independent variable proposed to reflect the level of sustainability of the municipality, DENSITY is the control variable proposed to identify the population density of each city, LEFT IDEOLOGY is the independent variable which reflects the ideology of the political parties in the municipal government, STABILITY is the independent variable which identifies the electoral support of the political parties in the municipal government, PARTIES is the independent variable which reflects the political competition in the municipality, UNEMPLOYMENT is the independent proxy variable for pressure from voters and interest groups.

Models (3) and (4) have been tested empirically through a linear regression, owing to the numerical nature of the dependent variable. The results of the analysis are given in the following section.

\section{Empirical results}

\subsection{Empirical results: the relationship between sustainability and economic development}

Table 2 depicts the results relating to the effect that a city's level of sustainability has on its economic development.

Model 1, proposed to test the effect of city sustainability on the economic development index, has an explanatory capacity of $71.30 \%$ for a confidence level of $99 \%$ (p-value $<0.01$ ). Of the six variables proposed, DENSITY, PARTIES and CSUS have a statistically significant positive effect, for a confidence level of $90 \%(0.05<\mathrm{p}$-value $<0.1)$ in the first case, and $99 \%$, in the last two cases. The variables STABILITY and LEFT have a positive effect on the municipal industrial index, although it lacks econometric relevance. For its part, UNEMPLOYMENT has a non-significant negative effect.

Model 2, designed to test the effect that city sustainability has on the municipal wholesale trade index, has an explanatory capacity of $74.50 \%$ for a confidence level of $99 \%$ ( $p$-value $<0.01$ ). Again, three of the six variables proposed, DENSITY, PARTIES and CSUS, have a direct and relevant 
Table 2: $\quad$ Impact of city sustainability on economic development.

\begin{tabular}{|c|c|c|c|c|c|c|c|c|}
\hline & \multirow{2}{*}{\multicolumn{2}{|c|}{$\begin{array}{c}\text { Model } 1 \\
\text { Industry Index }\end{array}$}} & \multirow{2}{*}{\multicolumn{2}{|c|}{$\begin{array}{c}\text { Model } 2 \\
\text { Trade Index }\end{array}$}} & \multirow{2}{*}{\multicolumn{2}{|c|}{$\begin{array}{c}\text { Model } 3 \\
\text { Trade Index }\end{array}$}} & \multirow{2}{*}{\multicolumn{2}{|c|}{$\begin{array}{c}\text { Model } 4 \\
\text { Services Index }\end{array}$}} \\
\hline & & & & & & & & \\
\hline & Beta & $t$ & Beta & $t$ & Beta & $t$ & Beta & $t$ \\
\hline (Constant) & & -6.5400 & & -7.2651 & & -8.0892 & & -5.9885 \\
\hline DENSITY & 0.0810 & $1.6736^{*}$ & 0.0802 & $1.7584^{*}$ & 0.0756 & $1.8434 *$ & 0.0147 & 0.2512 \\
\hline UNEMPLOY- & & & & & & & & \\
\hline MENT & -0.0394 & -0.8011 & 0.0582 & 1.2555 & 0.0172 & 0.4122 & 0.0844 & 1.3786 \\
\hline STABILITY & 0.0773 & 1.5361 & 0.0342 & 0.7215 & 0.0653 & 1.5297 & 0.0293 & 0.4957 \\
\hline PARTIES & 0.3417 & $6.1910 * * *$ & 0.3557 & $6.8333 * * *$ & 0.3731 & $7.9691 * * *$ & 0.3436 & $5_{.0518}^{* * *}$ \\
\hline LEFT & 0.0796 & 1.6141 & 0.0629 & 1.3537 & 0.0347 & 0.8297 & 0.0176 & 0.2938 \\
\hline \multirow[t]{3}{*}{ CSUS } & 0.5907 & $10.6869^{* * *}$ & 0.6136 & $11.7738 * *$ & 0.6250 & $13.3325 * * *$ & 0.6556 & $9.6359 * * *$ \\
\hline & $\mathbf{R}^{2}=$ & 0.713 & $\mathbf{R}^{2}=$ & 0.745 & $\mathbf{R}^{2}=$ & 0.794 & $\mathbf{R}^{2}=$ & 0.794 \\
\hline & $\mathbf{F}=$ & $52.557 * * *$ & $\mathbf{F}=$ & $61.739 * * *$ & $\mathbf{F}=$ & $81.292 * * *$ & $\mathbf{F}=$ & $45.702 * * *$ \\
\hline
\end{tabular}

econometric impact on the wholesale trade index of each city. The effect of each variable is significant for a confidence level of 90, $95(0.01<$ p-value $<0.05)$ and $99 \%$, respectively. The remaining variables - UNEMPLOYMENT, STABILITY and LEFT - have a positive effect on the economic index analysed, although it lacks explanatory importance from a statistical point of view.

Model 3, proposed to test the impact of city sustainability on the municipal retail trade index, has an explanatory capacity of $79.40 \%$ for a confidence level of $99 \%$ (p-value $<0.01$ ). Of the six variables proposed, three of them, DENSITY, PARTIES and CSUS, have a statistically significant positive effect for a confidence level of $90 \%(0.05<\mathrm{p}$-value $<0.1)$, for the first variable and $99 \%$, for the last two. The variables UNEMPLOYMENT, STABILITY and LEFT have a positive impact on the municipal industry index, although they lack econometric relevance.

Model 4, proposed to evidence the effect that city sustainability has on the municipal services index, has an explanatory capacity of $79.40 \%$ for a confidence level of $99 \%$ (p-value $<0.01$ ). In this model, only two of the six variables proposed are statistically significant for a confidence level of $99 \%$ : PARTIES and CSUS, both with a positive effect. The rest of the variablesDENSITY, UNEMPLOYMENT, STABILITY and LEFT - have a positive effect on the economic index analysed, although they lack explanatory relevance from a statistical point of view.

Given the results obtained for these four models, it can be concluded that municipal economic development is determined mainly by political competition and the city's level of sustainability. These results confirm our hypothesis H1. 
Table 3: Impact of political factors on city sustainability.

\begin{tabular}{|c|c|c|}
\hline & \multirow{2}{*}{\multicolumn{2}{|c|}{$\begin{array}{c}\text { Model 5 } \\
\text { City Sustainability }\end{array}$}} \\
\hline & & \\
\hline & Beta & B \\
\hline (Constant) & & 5.4487 \\
\hline DENSITY & 0.0127 & 0.1770 \\
\hline UNEMPLOYMENT & -0.2046 & $-2.8862 * * *$ \\
\hline STABILITY & -0.0491 & -0.6594 \\
\hline PARTIES & 0.5144 & $7.3360 * * *$ \\
\hline \multirow{3}{*}{ LEFT } & -0.2083 & $-2.9323 * * *$ \\
\hline & $\mathbf{R}^{2}=$ & 0.365 \\
\hline & $\mathbf{F}=$ & $14.303 * * *$ \\
\hline
\end{tabular}

\subsection{Empirical results: the relationship between political factors and sustainability}

Table 3 offers a synthesis of the results for model 5, proposed to observe the effect that political factors have on the level of city sustainability. This model has an explanatory capacity of $36.50 \%$, for a level of confidence of $99 \%$. Three of the five variables proposed, UNEMPLOYMENT, LEFT and PARTIES, have a statistically significant effect for a confidence level of $99 \%$. However, whereas PARTIES positively affects city sustainability, the first two variables do so negatively. The negative impact of the variable LEFT on city sustainability contradicts the relationship expected for these two factors in one of our hypotheses, and therefore hypothesis $\mathrm{H} 2$ should be accepted with the opposite sign to the one expected. The direct relationship between the political competition existing in each city, identified through the PARTIES variable, and the level of quality of life that characterized them allows us to accept hypothesis H4. The negative influence of the UNEMPLOYMENT variable, an inverse proxy for the pressure that voters and interest groups can exert on the government, leads us to accept hypothesis H5. The DENSITY and STABILITY variables have a positive and negative effect, respectively, which lack econometric relevance. This absence of significance of political stability leads us to reject hypothesis $\mathrm{H} 3$.

\section{Discussion of results}

In relation to our main research hypothesis, we have found that, considered overall, political systems have a significant effect on cities' sustainable development. More specifically, the existence of a high number of interest groups and political competition foster the evolution of the city. On the contrary, a leftist ideology of the ruling party negatively influences its evolution, whereas political stability - in relation to the percentage of votes obtained in the last general elections - does not have any impact on it.

These findings confirm the framework proposed by the Public Choice theory concerning the fact that political decisions about sustainable cities' strategies 
involve a trade-off between the real desires of politicians and the requirements of interest groups. This pressure may be even more effective in those cities where there is higher political competition and can involve a greater need for satisfying the interests of individuals who may support that political party in future elections, in order to ensure its re-election over its rivals.

The negative role played by ideology in urban sustainable development should be emphasised. This negative impact can be explained in two ways. The first of these is the positive impact that the quality of life of the city has on its economic development. The second may be linked to the fact that right-wing parties need to make a greater effort as regards sustainability than more progressive parties in order to attract a larger number of votes.

\section{Conclusions}

The economic development that took place in the last two decades of the $20^{\text {th }}$ century was stimulated to a large extent by urban growth. However, this development lacked a solid base that would permit sustainability in the long term. The greatest obstacles to the implementation of sustainable practices have most likely been related to political factors. Some authors consider that these obstacles appeared because pursuing sustainability objectives would deflect resources towards groups other than those originally foreseen or could go against the interest of groups with sufficient strength to put pressure on the governing party.

Based on the dual objective of this study, to test the impact of political factors on cities' sustainability and to observe what effect sustainability has on cities' business development, empirical evidence has been found that in some cases confirms and in other cases refutes the results of previous research.

In contrast to the conclusions of Jepson [25], we have verified the existence of a significant positive impact of certain political factors such as competition among political parties and the non-significance of others such as the stability of local government on the economic progress of cities and a lesser effect on their sustainability.

The empirical evidence shows the existence of a non-significant positive relationship between a party in power with a progressive ideology and economic development, whereas, in contrast to what was expected, there is a significant negative relationship between a left-wing governing party and sustainable development in cities. This may be because right-wing parties make an extra effort in matters of sustainability in order to attract voters with a progressive tendency.

In this line, a significant positive relationship was observed between the degree of a city's sustainability and the economic activity taking place in it, be it related to industry, trade or services. This allows us to conclude that a city's economic development can be explained to a certain extent by the degree of competition among parties and the level of that city's sustainability.

It was also found that pressure from interest groups induces parties to promote policies related to sustainability in spite of their initial reticence, with 
the clear objective of their future re-election. Logically, this pressure is more effective in cities with a large degree of political competition.

\section{References}

[1] Konvitz, J.W., Cities and the global economy, The OECD Observer, 197, pp. 6-8, 1996.

[2] Glaser, M., The business psyche: Exploring relationships between local quality of life and city image. Public Administration Quarterly, 15(3), pp 287-303, 1991.

[3] Insch, A., \& Florek, M., A great place to live, work and play. Journal of Place Management and Development, 1(2), pp. 138-149, 2008.

[4] Hogwood, B.W., \& Gunn, L.A., Policy Analysis for the Real World, Oxford University Press, Oxford, 1984.

[5] García-Sánchez, I.M., \& Prado-Lorenzo, J.M., Determinant factors in the degree of implementation of Local Agenda 21 in the European Union. Sustainable Development, 16, pp. 17-34, 2008.

[6] Rotmans, J., \& Van Asselt, M., Towards an integrated approach for sustainable city planning. Journal of Multi-Criteria Decision Analysis, 9, pp. 110-124, 2000.

[7] Wang, X. \& Lihua, R., Examining knowledge management factors in the creation of new city. Journal of Technology Management in China, 1(3), pp. 243-261, 2006.

[8] World Commission Environment and Development, Our Common Future, Oxford, U.K.: Oxford University Press, 1987.

[9] Zeijl-Rozema, A., Cövers, R., Kemp, R., \& Martens, P., Governance for sustainable development: A framework. Sustainable Development, 16, pp. 410-421, 2008.

[10] Dempsey, N., Bramley, G., Power, S., \& Brown, C., The social dimension of sustainable development: Defining urban social sustainability. Sustainable Development, DOI: 10.1002/sd.417.

[11] Williams, A., Kitchen, P., Randall, J., \& Muhajarine, N., Changes in quality of life perceptions in Saskatoon, Saskatchewan: comparing survey results from 2001 and 2004. Social Indicators Research, 85, pp. 5-21, 2008.

[12] Biel, A., Converting image into equity in Brand Equity and Advertising: Advertising's role in building strong brands, Lawrence Erlbaum, Hillsdale, Nh., 1993.

[13] Kotler, P., Haider, d., \& Rein., I., Marketing places: attracting investment, industry and tourism to cities, states and nations. The Free Press, New York, 1993.

[14] Campbell, S., Green cities, growing cities, just cities? Urban planning and the contradictions of sustainable development. Journal of the American Planning Association, 62, pp. 296-313, 1996.

[15] Blowers, A. "The time for change", in Planning for a sustainable environments, ed. A. Blowers, Earthscan, London, 1993. 
[16] Berke, P.R. \& French, S.P., The influence of state planning on local plan quality. Journal of Planning Education and Research 13, pp. 237-250, 1994.

[17] Berke, P.R., Roegnik, D.J., Kaiser, E.J. \& Burby, R., Enhancing plan quality: evaluating the role of state planning mandates for natural hazard mitigation. Journal of Environmental Planning and Management 39, pp. 79-96, 1996.

[18] Mueller, D.C., Public Choice, University Press, Cambridge, 1979.

[19] Bavetta, S. \& Padovano, F., A model of the representation of interest in a compound democracy. Constitutional Political Economy, 11(1), pp. 5-25, 2000.

[20] Prado-Lorenzo, J.M. \& García-Sánchez, I.M., Decisive factors in the creation and execution of municipal action plans in the field of sustainable development in the European Union. Journal of Cleaner Production, 17, pp. 1039-1051, 2009.

[21] Ni, A.Y., \& Bretschneider, S., The decision to contract out: A study of contracting for e-government services in state governments. Public Administration Review, 67(3), pp. 531-544, 2007.

[22] Smith, D.A., \& Fridkin, D., Delegating direct democracy: Interparty legislative competition and the adoption of the initiative in the American States. American Political Science Review, 102(3), pp. 333-350, 2008.

[23] Cheng, R.H., An empirical analysis of theories on factors influencing state government accounting disclosure. Journal of Accounting and Public Policy, 11, pp. 1-42, 1992.

[24] Camagni, R., Cities and the Quality of life: Problems and Prospects. Review of Economic Conditions in Italy, 1, pp. 61, 2000.

[25] Jepson, E.J., The adoption of sustainable development policies and techniques in U.S. cities. Journal of Planning Education and Research, 23(3), pp. 229-241, 2004. 